\title{
Emesis-induced facial purpura as a mask phenomenon
}

\author{
Ryohei Ono (1) 1,2 Hidehisa Takahashi, ${ }^{2}$ Kenichi Fukushima ${ }^{2}$
}

${ }^{1}$ Department of Cardiovascular Medicine, Chiba University Graduate School of Medicine, Chiba, Japan

2Department of Cardiology, Matsudo City General Hospital, Matsudo, Chiba, Japan

\section{Correspondence to}

Dr Ryohei Ono;

ryohei_ono_0820@yahoo.co.jp

Accepted 4 February 2021

Check for updates

(c) BMJ Publishing Group Limited 2021. No commercial re-use. See rights and permissions. Published by BMJ.

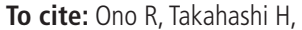
Fukushima K. BMJ Case Rep 2021;14:e241456. doi:10.1136/bcr-2020241456

\section{DESCRIPTION}

A healthy 20-year-old man presented with acute facial purpuric lesions after forceful vomiting (figure 1). He vomited due to overeating, and the patient noticed his facial purpura soon after the emesis when looking at his face in the bathroom mirror. The patient denied experiencing pruritus or pain of the lesions. He had no known allergies and was not on any medications. Physical examination revealed non-palpable purpura on his face; however, it was not present on his arms, legs and trunk. Other physical examinations revealed unremarkable findings. Laboratory investigations and the workup for vasculitis revealed within normal levels of serum creatinine $(0.78 \mathrm{mg} / \mathrm{dL}$ (reference range: $0.50-1.30 \mathrm{mg} /$ $\mathrm{dL})$ ), white blood cell count $\left(5200 / \mathrm{mm}^{3}\right.$ (reference range: $\left.3300-8600 / \mathrm{mm}^{3}\right)$ ), platelet count (251 000/. $\mathrm{mm}^{3}$ (reference range: 150000-350 $\left.\left.000 / \mathrm{mm}^{3}\right)\right), \operatorname{IgA}(116 \mathrm{mg} / \mathrm{dL}$ (reference range: $110-410 \mathrm{mg} / \mathrm{dL})$ ), complement component 3 (78 $\mathrm{mg} / \mathrm{dL}$ (reference range: $65-135 \mathrm{mg} / \mathrm{dL}$ )) and complement component $4(17 \mathrm{mg} / \mathrm{dL}$ (reference range: $13-35 \mathrm{mg} / \mathrm{dL})$ ) with negative antinuclear antibody test. Neither proteinuria nor haematuria was detected in the urinalysis.

We diagnosed emesis-induced petechial rash as a mask phenomenon, and the purpura faded spontaneously after approximately 48 hours without treatment. Skin biopsy was not performed.

The mask phenomenon is known as an unusual purpura of the relatively loose tissues of the face and neck occurring after severe straining that raises intravascular pressure, such as vomiting, prolonged coughing, crying, infant delivery or the Valsalva manoeuvre. ${ }^{12}$ The purpura typically fades within a few days without treatment; thus, invasive interventions are not required. ${ }^{3}$ The differential diagnoses of facial purpura include IgA vasculitis, systemic lupus erythematosus, senile purpura, actinic purpura, thrombocytopenic purpura, acute haemorrhagic oedema, purpura fulminans, amyloidosis, drug eruption and trauma. ${ }^{245}$ Physicians should keep in mind the possibility of a mask phenomenon when patients have facial purpura after straining.

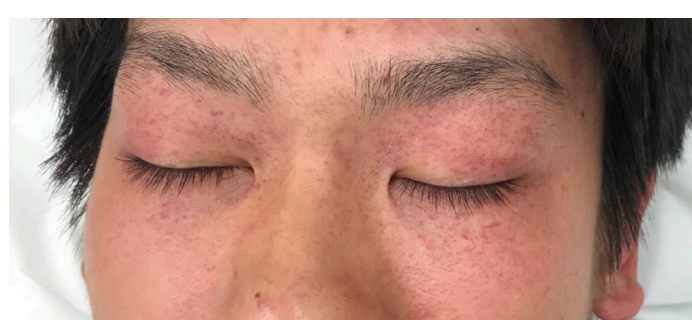

Figure 1 A physical examination showing non-palpable facial purpuric lesions after the emesis.

\section{Learning points}

- Mask phenomenon is a purpura of the loose tissues of the face and neck occurring after severe straining.

- The purpura typically fades within a few days without treatment.

- Invasive interventions are not required for the mask phenomenon.

Contributors RO contributed to patient management, conception and design of case report and drafting the article. $\mathrm{HT}$ and $\mathrm{KF}$ contributed to analysis and interpretation of data and revising the article. All authors gave final approval of the article and have agreed to be accountable for all aspects of the work.

Funding The authors have not declared a specific grant for this research from any funding agency in the public, commercial or not-for-profit sectors.

Competing interests None declared.

Patient consent for publication Obtained.

Provenance and peer review Not commissioned; externally peer reviewed.

ORCID iD

Ryohei Ono http://orcid.org/0000-0002-4875-7470

\section{REFERENCES}

1 Alcalay J, Ingber A, Sandbank M. Mask phenomenon: postemesis facial purpura. Cutis 1986;38:28.

2 Vañó-Galván S, Muñoz-Zato E. Acute facial purpura in an 82-yearold woman with a respiratory tract infection. Cleve Clin J Med 2008:75:352.

3 Kaliyadan F, Kuruvilla JP. Post-vomiting purpura. Indian Dermatol Online J 2016;7:456-7.

4 Chin X, Chan DKL, Chong JH. A rash that's more than skin deep. BMJ 2018;360:k8.

5 Goldman AC, Govindaraj S, Franco RA, et al. Facial purpura. Laryngoscope 2001;111:207-12. 
Copyright 2021 BMJ Publishing Group. All rights reserved. For permission to reuse any of this content visit https://www.bmj.com/company/products-services/rights-and-licensing/permissions/

BMJ Case Report Fellows may re-use this article for personal use and teaching without any further permission.

Become a Fellow of BMJ Case Reports today and you can:

- Submit as many cases as you like

- Enjoy fast sympathetic peer review and rapid publication of accepted articles

Access all the published articles

Re-use any of the published material for personal use and teaching without further permission

Customer Service

If you have any further queries about your subscription, please contact our customer services team on +44 (0) 2071111105 or via email at support@bmj.com.

Visit casereports.bmj.com for more articles like this and to become a Fellow 